also seen another specimen of the same description. Can it be that these two specimens have been manufactured by Malays for whetstones out of the so-called thunder-stones? I cannot account for them in any other way; they are too slight for hammers.

For my part, I have always found the Sakaies especially wanting in every respect as to traditions beyond the memory of their own generation, and they have invariably answered my inquiries as to the origin of the stone axes by saying, like the Malays, that they are thunder-stones. To such an extent is this belief held by Malays, that the other day a Malay of considerable social standing assured me that once a cocoa-nut palm was struck by lightning close to his house, and that about a month afterwards he searched about the roots of the tree and found the thunder-stone which was the cause of the damage: it was this man's father who for several years kept a fire alight in his house, which fire was generated from the same tree after it had been struck by the electric current.

I have already drawn attention to the Malay belief as to these so-called thunder-stones (NATURE, vol. xxxii. p. 626). My specimens are all in the Perak Museum at Thaiping.

Kinta Perak, April 5

A. Hale

On a Thermo-electrical Phenomenon in Connection with Prof. Balfour Stewart's Paper on Terrestrial Magnetism

In the Philosophical Magazine for May Prof. Balfour Stewart, in his paper "On the Causes of the Solar-Diurnal Variation of Terrestrial Magnetism," takes in one place (p. 443), for an example, the case of "an ordinary electric circuit, say of a circular shape, and horizontal, and heat it by causing some source of heat, such as a lamp, to travel slowly around it with a definite rate of progress." He goes on to say that no current due to the heating will take place. So it would generally be thought. If, however, the experiment be even roughly tried, a all events with an iron or nickel wire, the contrary takes place. An account of the experiments, \&c., which I have made on this subject, was read before the Royal Dublin Society on March 24 and will, in the course of time, be printed in the Society's Proccedings. Though there is a current in a wire on causing a heated portion to travel along it, it seems unlikely from the nature of the phenomenon that it could in any way be inferred that the higher air would similarly affect a current under the sun's heating.

Physical Laboratory, Trinity College, Dublin

\section{Do Migratory Birds Return to their Old Haunts?}

MuCH evidence has been given by naturalists to prove that birds of passage return to their old haunts. The following, I think, may be of interest to some of the readers of your valuable paper. For the past two springs a cuckoo gifted with a decidedly peculiar note has visited this neighbourhood. Within the last fortnight it has again arrived. Its song consists of three clear distinct notes, cuck-coo-coo, the second note being a semitone above the last. This it never varies. We all know that towards the end of its sojourn the cuckoo suffers from hoarseness, or as the country people say, "changes its tune." Although this bird suffers in a similar way, yet it still maintains its peculiar song-three notes. As far as I can ascertain, it does not wander beyond the same limits-from the park here to a little hill about half a mile distant. I think these facts not only conclusively prove that the cuckoo returns to its old quarters year after year, bnt that it also restricts itself during its stay in this country to the same locality.

Summerleaze, East Harptree, May I3

\section{The Poison of the Stinging-Nettle}

IN the interesting article in your issue for May 6 (p. 5), on "Plants and their Defences," there is one sentence on which I should like to be allowed to offer a few remarks. It runs thus :- "This fluid [of the stinging-gland of the stinging-nettle] is generally conjectured to be formic acid-a view based on the fact that this acid can be obtained from the nettle-plant by suitable means." Does this "conjecture" rest on any other basis than the similarity of the effect produced by the sting of the nettle and the bite of the ant? I am inclined to think not. Certainly the fact that formic acid can be obtained from the nettle-plant is not in itself a cogent argument, seeing that it has been shown that this acid is a widely-spread constituent of the cell-sap of living plants. The formic acid theory is also out of harmony with the fact that the fluid contained in the stingingglands of the nettle has frequently, if not always, an alkaline reaction. It seems strange that we have at present no trustworthy observations on so interesting a question. Can none of our physiological chemists come forward and remove it from the region of conjecture?

St. Thomas's Hospital, May 13

\section{What is Histioderma?}

CAN any of the readers of NATURE inform me to what class of fossil organisms belongs the genus Histioderma? Mention of the name-but of the name only-is made by Sterry Hunt in this journal, vol. vi. (1872), p. 54, and by Hicks in the Quarterly Fournal of the Geological Society of London, vol. xxix. part I, I873, table facing p. 42. It does not occur in Broun's "Index Palæontologica," in Pfeiffer's " Nomenclator Botanicus," nor in Scudder's " Zoological Nomenclator." The name is not to be confounded with that of Carter's genus, Histoderma, established $\mathbf{1 8 7 4}$, for recent sponges.

Leyden, May 15

\section{ON THE INFLUENCE OF FORESTS ON THE CLIMATE OF SWEDEN ${ }^{1}$}

$A$ VALUABLE Report on this subject has been prepared by Dr. H. E. Hamberg, and printed as an appendix to the Report of the Forest Commissioners of Sweden for the year 1885 . The observations were commenced in I 876 , on the principles established by Dr. Ebermayer in Bavaria, but Dr. Hamberg soon found that the mere comparison of the results obtained at the forest station with those yielded by its sister station in the open country was insufficient to bring out all the peculiarities of forest influence, and accordingly he added a third class of station, situated in a clearing in the forest itself (öppen plats $i$ skogen). The various results of these observations are discussed in a very exhaustive manner, and we must refer those interested in the subject to the Report itself. The author's conclusions, however, are very interesting, and are reproduced here in full.

"Our researches do not allow us to determine whether the presence of the forests on the whole contributes to increase or diminish the quantity of heat in the atmosphere, that is to say, to raise or lower its temperature. In fact, we have been entirely unable to take into account either solar radiation or the radiation from the needles ${ }^{2}$ and the points of the trees. Until we are able to ascertain the quantity of heat which escapes from these surfaces, and its relation to that escaping from other surfaces, it is quite impossible to determine with certainty the influence of the forest on such an important subject as the mean temperature, and must confine ourselves to approximate estimations. Among the various surfaces which are met with in Sweden the most important are assuredly water, bare ground or rock, soil covered by herbage, and finally forest Neither the surface of the lakes and sea nor the bare soil of town streets have any resemblance to the forest: the climate of the latter bears no similarity to a maritime climate or a town climate. A forest may best be considered as an instance of vegetation on a gigantic scale, as is evident from the low temperature of the ground under the trees, and the freshness of the air in summer, especially in the evening and at night-time, thus affording evidence of active radiation. In this case the forest would be a source of cold rather than of heat. But here we are simply dealing with suppositions.

"From this point of view a forest is distinguished from all the other surfaces we have mentioned, in that it extends into a stratum of air lying far above that in which man lives and carries on all of his occupations which depend on

x "Om skogarnes inflytande pă Sveriges klimat." From Quart. 7 ourna Roy. Met. Soc. for April 1886 , communicated by Mr. R. H. Scott, F.R.S.
The forests dealt with were entirely of pines and firs. 